Note

\title{
High fire temperature changes soil aggregate stability in slash-and-burn agricultural systems
}

\author{
Edivaldo Lopes Thomaz
}

Midwest State University - Dept. of Geography - Soil Erosion Lab., R. Simeão Camargo Varela de Sá, 03, C.P. 3010 - 85040-080 - Guarapuava, PR - Brazil. e-mail <thomaz@unicentro.br>

Edited by: Leônidas Carrijo Azevedo Melo

Received January 07, 2016

Accepted April 20, 2016

\begin{abstract}
Fire is a key controlling factor in ecosystem dynamics worldwide, especially, in tropical areas under slash-and-burn agricultural systems. Farmers use fire as a tool to clean the land, and benefit from nutrient enrichment from ash-soil heating. However, fire can cause some detrimental effects on soil systems, such as organic carbon depletion, increased soil erodibility, and changes to aggregate stability. In this study, an experimental fire was applied to a plot of land following the local traditional practice of slash-and-burn. The fire temperature was monitored in the field, and its effect on soil aggregate stability was assessed. The fire temperature on soil surface was measured in four trenches, and it ranged from 355 to $660{ }^{\circ} \mathrm{C}$ (average $484 \pm$ $142^{\circ} \mathrm{C}$ ). The fire temperature did not affect soil organic matter content. However, aggregate stability increased by $10 \%$ in comparison to unburned soil. Moreover, the geometric mean diameter of burned soil was $20 \%$ higher than that of unburned soil. In conclusion, high fire temperature changes soil aggregate stability in slash-and-burn agricultural systems.

Keywords: burn severity, prescribed fire, soil erodibility, marginal land, subsistence agriculture
\end{abstract}

\section{Introduction}

The soil is a key component of the Earth system that control the biological, hydrological, geomorphological and geochemical cycles. In addition, the soil is a source of resources, goods and services for humankind (Keesstra et al., 2012; Brevik et al., 2015; Hedo et al., 2015; Smith et al., 2015; Wang et al., 2015). Fires have proven to significantly change the hydrological and geomorphological processes in hillslope (Lasanta and Cerdà, 2005; Shakesby and Doerr, 2006; Keesstra et al., 2014). Post-fire topsoil dramatically alters soil system functionality (Bodí et al., 2014; Doerr and Cerdà, 2005; Cerdà and Doerr, 2008; Pereira et al., 2015).

Most studies that investigate fire effects on soil properties have assessed mostly wildfire conditions (Bento-Gonçalves et al., 2012; Certini, 2005; DeBano, 2000; Shakesby and Doerr, 2006). Furthermore, in a recent review of fire effects on soil aggregation, most studies were conducted in Spain, that is, a Mediterranean ecosystem (Mataix-Solera et al., 2011). Only one study discussed in that review focused on the effects of slash-and-burn agricultural systems on soil quality in tropical environments (Are et al., 2009). In addition, no-tillage is practiced in the slash-and-burn agriculture as one of oldest system of soil management (Cerri et al., 2007).

Despite agricultural modernization, the slash-andburn system is prevalent in tropical regions, such as Latin America (Grau and Brown, 2000; Silva-Forsberg and Fearnside 1997; Thomaz, 2013), Africa (Are et al., 2009; Ngo-Mbogba et al., 2015; Obale-Ebanga et al., 2003), and Asia (Bruun et al., 2009; Liao et al., 2015; Tanaka et al., 2005).
In spite of recent worldwide changes in slashand-burn systems (e.g., economic and demographic changes, environmental impact, fallow length, etc.) (van Vliet et al., 2012), this agricultural system will persist as an important land-use and subsistence strategy in tropical countries for many years (Mukul and Herbohn, 2016). Overall, studies on soil physics and soil hydrology, that is, soil erosion, soil infiltration capacity, soil structural stability, are still limited (Mukul and Herbohn, 2016). Here, different fire intensities measured at field conditions were evaluated in relation to their effect on the structural stability of tropical soil under slash-and-burn systems.

\section{Materials and Methods}

\section{Site characteristics}

This study was carried out at the Faxinal System, located in the rural community of Tijuco Preto in the Prudentópolis municipality of southern Brazil $\left(25^{\circ} 23^{\prime} 46.6^{\prime \prime} \mathrm{S}, 51^{\circ} 6^{\prime} 21.7^{\prime \prime} \mathrm{W}\right)$ (Figure 1). The altitude of the site averages $800 \mathrm{~m}$ (above sea level). The study site, typical for the region, covers 17 ha in size and under shifting cultivation. It was chosen to assess the effects of fire on the physical and chemical properties of soil (Table 1). The climate is classified as a Cfb (humid temperate climate with temperate summer) temperate climate with average temperatures during the coldest month below $18{ }^{\circ} \mathrm{C}$ (mesothermal), cool summers with average temperatures during the warmest month below $22{ }^{\circ} \mathrm{C}$, and no dry season. Annual averages range from 1600 to $1800 \mathrm{~mm}$ for rainfall, 900 to $1000 \mathrm{~mm}$ for evapotranspiration, and 16 to $18{ }^{\circ} \mathrm{C}$ for temperatures /Caviglione et al., 2000). 
Table 1 - Soil Characteristics.

\begin{tabular}{|c|c|}
\hline Soil type: Cambisol (IUSS Working Group WRB, 20 & Sand Silt Clay \\
\hline & $-\mathrm{kg} \mathrm{kg}^{-1}$ \\
\hline Soil depth $(0-20 \mathrm{~cm})$ & $323 \quad 331 \quad 345$ \\
\hline Chemical content & $0-20 \mathrm{~cm}$ \\
\hline $\mathrm{pH}\left(\mathrm{CaCl}_{2} 0.01 \mathrm{M}\right)$ & 3.4 \\
\hline Soil organic matter ( $\mathrm{g} \mathrm{kg}^{-1}$ ) (Walkley-Black, 1934) & 28.0 \\
\hline $\mathrm{P}$ (Mehlich) (mg kg-1) & 1.9 \\
\hline $\mathrm{CEC}\left(\mathrm{cmol} \mathrm{kg}^{-1}\right)$ & 21.7 \\
\hline Base saturation (\%) & 16.9 \\
\hline
\end{tabular}
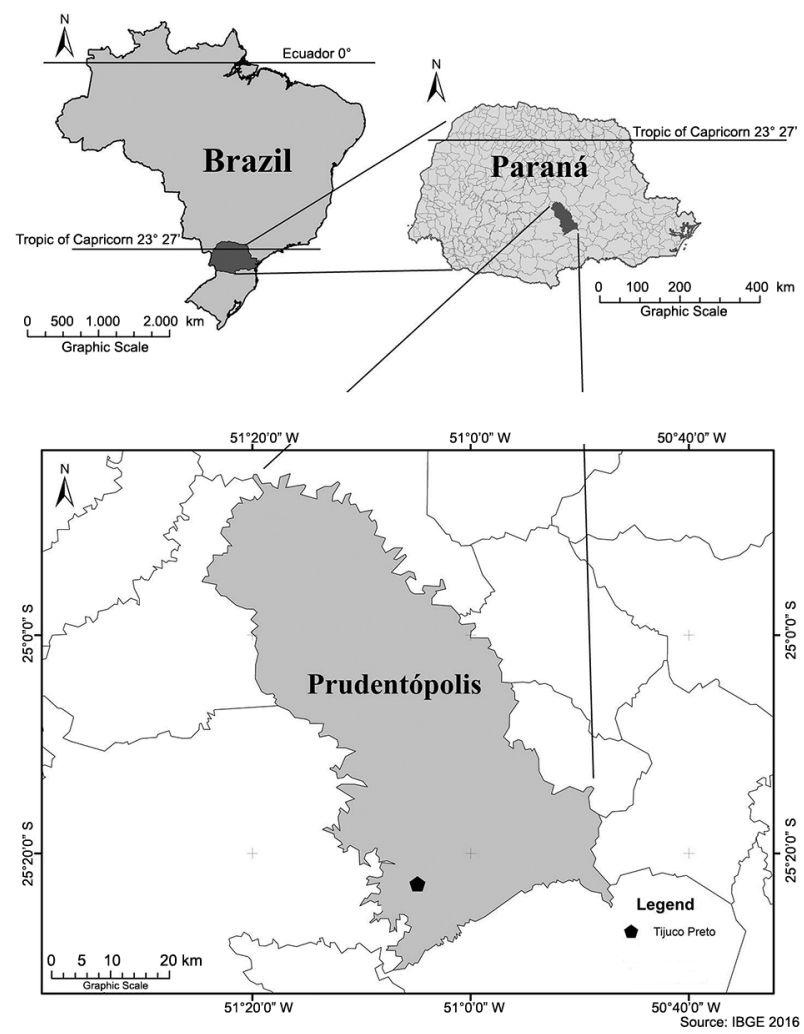

Figure 1 - Location of the study site.

\section{Measurement design}

A 1.5-ha plot with $44 \pm 15 \mathrm{Mg} \mathrm{ha}^{-1}(\mathrm{n}=12)$ of biomass was slashed, dried, and burned, according to the local slash-and-burn system for cropping maize and black beans. Four trenches covered with biomass were monitored during the course of this study. A set of three thermocouples was placed in each trench at the following depths: $0 \mathrm{~cm}$ on top of the mineral horizon beneath the litter layer, $1.0 \mathrm{~cm}$ within the mineral horizon, and 2 $\mathrm{cm}$ within the mineral horizon.

Three soil samples were collected with a metal ring (50 $\mathrm{cm}^{3}$ in volume, $2.5 \mathrm{~cm}$ in height) at depths $0-2.5$ $\mathrm{cm}$. The samples were collected approximately $12 \mathrm{~h}$ after the fire. The samples were collected at distances no greater than $50 \mathrm{~cm}$ from the trench center. This procedure ensured that the measurements accurately reflected the relationship between the registered temperatures and the associated temperature effects on soil properties. Unburned soil samples collected before the fire were used as control.

\section{Measurement of soil physical properties}

Three soil samples closer to the thermocouples were collected and split into six samples. Through wet sieving (WS), the samples were then fractionated according to the following sieve sizes: $4.0,2.0,1.0,0.5,0.25$, and $0.125 \mathrm{~mm}$. The soil samples (25 g) were subjected to immersion for capillary wetting, and the material remained in this condition for $5 \mathrm{~min}$. The material was then shaken gently with upward and downward movements for $20 \mathrm{~min}$ at $40 \mathrm{rpm}$. The material removed from the sieves was dried $\left(105^{\circ} \mathrm{C}\right.$ for $\left.24 \mathrm{~h}\right)$ and weighed. The sand fraction was collected through a sieve with 0.053 mm mesh.

The distribution and quantity of aggregates (weight and percentage) were measured using the percentage of aggregate amounts retained in each sieve in relation to the total sample amount. The sand fraction contained in the aggregates was discarded in the analysis. Indices of the aggregates - the aggregate stability index (AS \%) (Equation 1) and the geometric mean diameter (GMD) (Equation 2) - were obtained using the equations below. Each treatment (unburned and four measured temperatures) had six replicates for comparison in order to detect temperature effects on soil aggregate stability.

Results of the indices described above can have different interpretations. The percentage of AS can vary from 1 to $100 \%$ and indicate the aggregation, whereas the GMD is used to indicate the class of aggregates found most frequently in the soil (Castro Filho et al., 2002; Hillel, 1998).

$A S \%=\frac{W A-W I-S}{W-S} \times 100$

(Equation 1)

where: AS\% = aggregate stability as a percentage, WA = weight of aggregates $>0.25 \mathrm{~mm}, \mathrm{WI}=$ weight of aggregates $<0.25 \mathrm{~mm}, \mathrm{~W}=$ sample weight, and $\mathrm{S}=$ sand .

$G M D=\exp \left(\frac{\sum w_{i} \log x_{i}}{\sum w s_{i}}\right)$

(Equation 2)

where: GMD = geometric mean diameter, $w_{i}=$ weight of the aggregates of each size class $(\mathrm{g}), \log x_{i}=\operatorname{logarithm}$ of the mean diameter of the size classes, $w s_{i}=$ sample weight.

Soil organic matter was analyzed using three soil samples collected with a metal ring $\left(50 \mathrm{~cm}^{3}\right.$ in volume, $2.5 \mathrm{~cm}$ in height) at depths $0-2.5 \mathrm{~cm}$. The samples were collected approximately $12 \mathrm{~h}$ after the fire. The samples were collected at distances no greater than $50 \mathrm{~cm}$ from the center of the trench. Soil organic matter content was determined by the Walkley-Black method (Walkley and Black, 1934). 


\section{Data analysis}

The analysis of variance (ANOVA) of the soil parameters was performed to compare soil properties in each treatment before and after soil heating. Differences between individual averages were tested using the posthoc Dunnett test at $p<0.05$, since the objective was to compare fire effects on soil properties in relation to unburned soil (control samples). The samples were checked for homoscedasticity and normality (Shapiro-Wilk). Additionally, a simple correlation analysis was performed to evaluate the response of the geometric mean diameter changes following the temperature gradient.

\section{Results and Discussion}

\section{Fire temperature dynamics}

Surface soil fire temperatures measured in the four trenches ranged from 355 to $660{ }^{\circ} \mathrm{C}$ (average $484 \pm 142$ ${ }^{\circ} \mathrm{C}$ ) (Figure 2A). The temperature dropped abruptly between depths $1 \mathrm{~cm}$ and $2 \mathrm{~cm}$, and was slightly above 56 ${ }^{\circ} \mathrm{C}$ at both depths. In addition, the higher the temperature, the shorter was its residence time (Figure 2B). The temperatures registered were similar to those found in the literature, since high surface temperatures persist for only a few seconds (Bento-Gonçalves et al., 2012) and temperature decreases at depth (DeBano et al., 1998).

Fire severity or burn severity is related to fire intensity (peak temperatures and energy release) and temperature residence time (Keeley, 2009). In the study site, the temperature recorded ranged from moderate (355 $\left.{ }^{\circ} \mathrm{C}\right)$ to high $\left(660{ }^{\circ} \mathrm{C}\right)$. Therefore, ecosystem responses such as soil erodibility and changes in soil aggregation are expected. Critical changes in physical, chemical, and

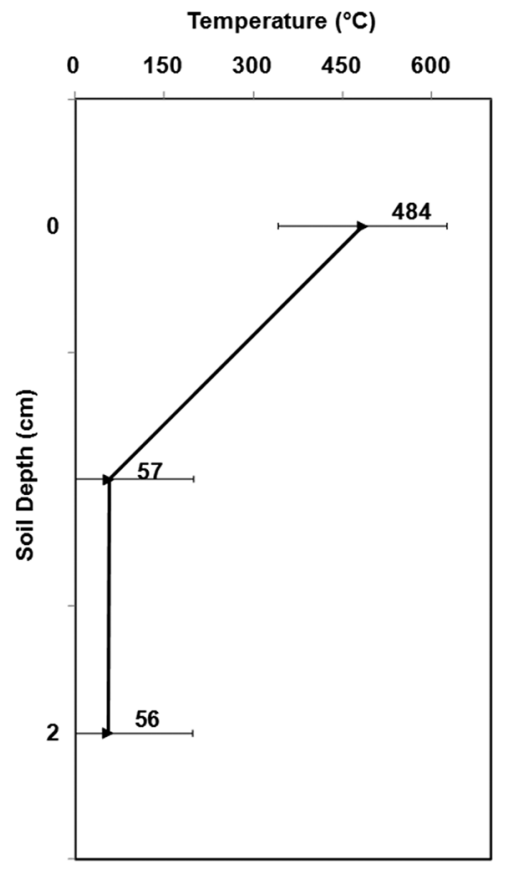

mineralogical soil properties can be expected in soil systems influenced by severe fire (Certini, 2005; DeBano et al., 1998; Ulery and Graham, 1993). In this study, a noticeable change in soil aggregate stability due to fire temperature was detected and it will be explained further.

Fire temperature effects on organic matter and aggregate stability

In this study, the fire temperature did not affect soil organic matter content (Figure 3A). Despite the high temperatures prevalent in the burned soil, no significant loss of organic matter (OM) was observed. One possible explanation for this may be the peak temperature that did not last long enough to reduce OM (Figure 2B). Additionally, the topsoil was rich in large aggregates (4-8 $\mathrm{mm})$, which may have had a protective effect on OM because much of it was located inside of aggregates isolated from the high surface temperatures. In a previous study, we observed no effect of fire on soil organic depletion at topsoil, that is, $2.5 \mathrm{~cm}$ at depth (Thomaz et al., 2014). In contrast, we observed, in a laboratory experiment, that a temperature of $250{ }^{\circ} \mathrm{C}$ lasting $15 \mathrm{~min}$ was enough to reduce OM (Thomaz and Fachin, 2014). However, field experiments are complex, and many variables cannot be controlled properly (e.g., fire intensity, soil moisture, soil texture, etc.). Conversely, results obtained in the laboratory are not translated directly into the field-scale effects of fire (Úbeda and Outeiro, 2009).

Aggregate stability increased only at the highest temperature, in comparison to unburned soil and other lower temperatures (Figure 3B). Aggregate stability was $10 \%$ higher in comparison to unburned soil. Overall, the slash-and-burn agricultural system displayed stable

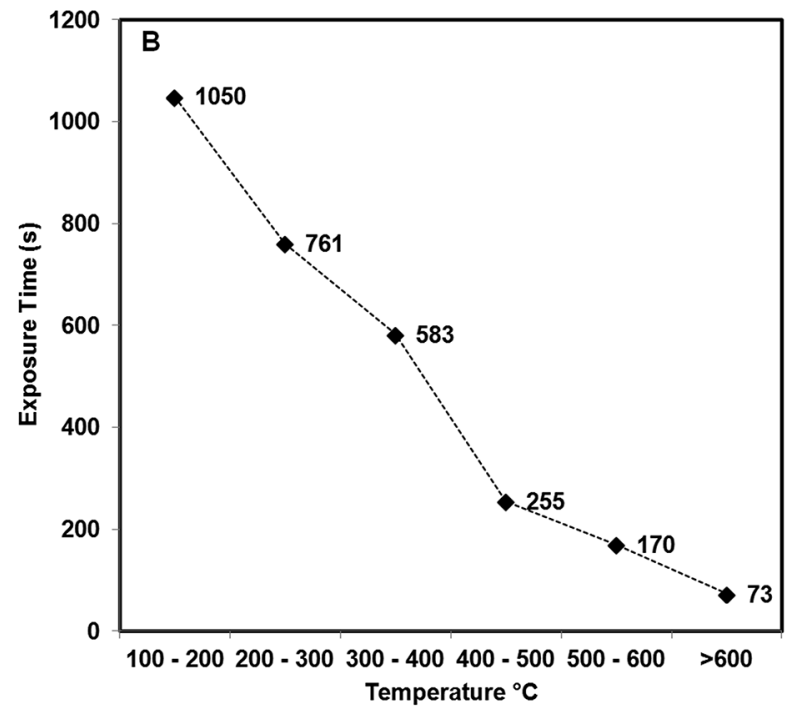

Figure 2 - Fire temperature dynamic: A) temperature in soil profile; B) residence time according to temperature class. 

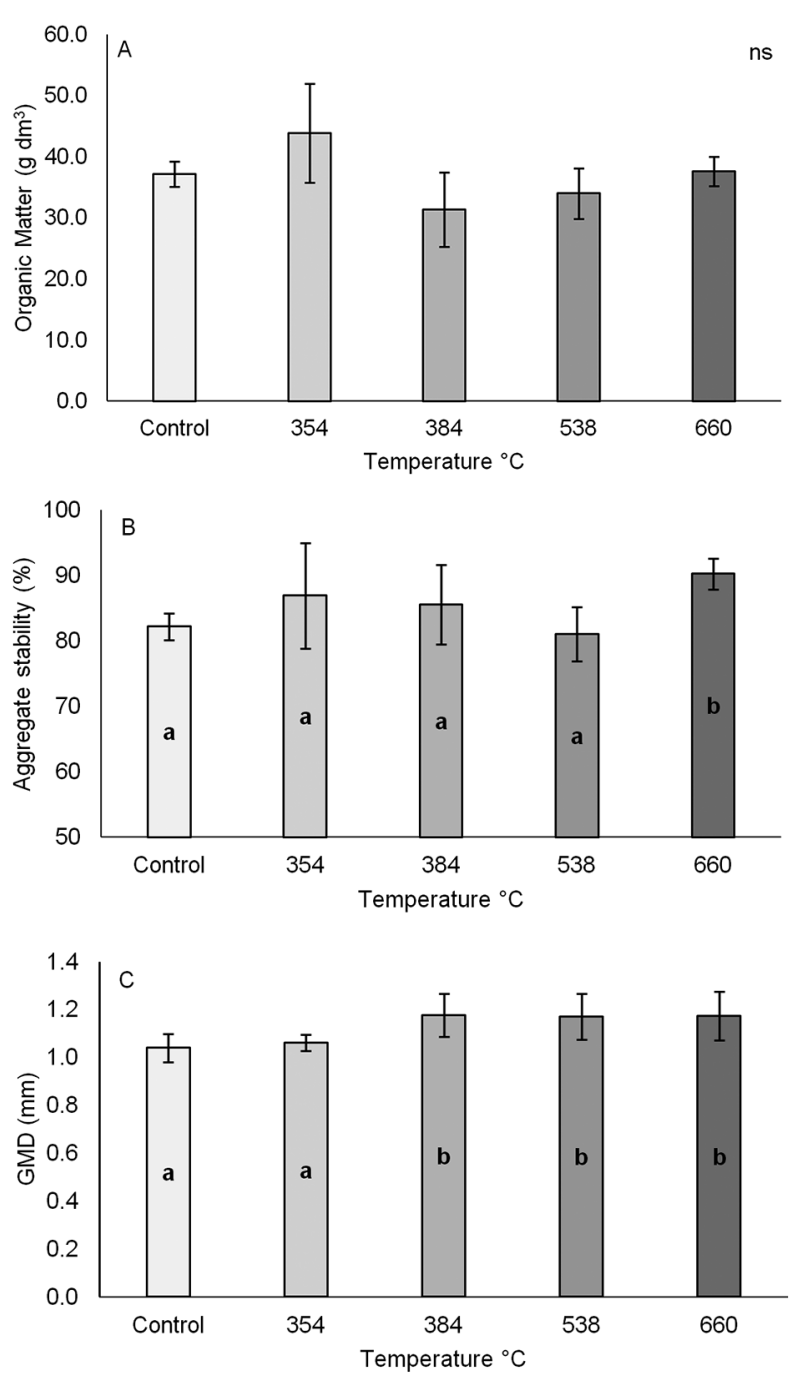

Figure 3 - Effects of fire on soil properties according to temperature gradient: A) Organic matter content; B) Aggregate stability increases at very high temperature; C) Geometric mean diameter increases at moderate to very high temperature. The same lowercase letters in the bars indicate no significant difference at $0.05 \%$ level according to Dunnett test.

aggregates in the topsoil ( $82 \pm 6 \%$; average), in relation to the unburned soil. However, the increase in aggregate stability at the highest temperature could be ascribed to the effect of fire on the topsoil.

Furthermore, the geometric mean diameter (GMD) of burned soil increased by $20 \%$ in comparison to the unburned soil (Figure 3C). In other words, larger aggregates became more frequent in burned soil than in unburned soil, and GMD increased from $\geq 1.0 \pm 0.1 \mathrm{~mm}$ in the unburned soil to $\geq 1.2 \pm 0.1 \mathrm{~mm}$ at the highest temperature $\left(660{ }^{\circ} \mathrm{C}\right)$. Moderate temperature $\left(354^{\circ} \mathrm{C}\right)$ was not sufficient to change aggregate stability. Overall, GMD increased linearly from unburned soil to the highest temperature $(\mathrm{r}=0.813, p=0.09)$.
In this study, soil physical properties were affected by fire: in particular, aggregate stability at the highest temperature, and geometric mean diameter at moderateto-high temperatures. In tropical soil, aggregate stability is associated with the presence of $\mathrm{Fe}$ and $\mathrm{Al}$ oxides. These oxides act as the main cementing agents along with organic matter in the soil (Amézketa, 1999; Tisdall and Oades, 1982).

Aggregate stability tends to be high in tropical soils, even under fire activity. Aggregate stability increases in tropical soils when subjected to fires of medium-tohigh severity (Mataix-Solera et al., 2011). Temperatures higher than $400{ }^{\circ} \mathrm{C}$ transform mineral components of the soil, such as $\mathrm{Fe}$ and $\mathrm{Al}$ oxyhydroxides, through the process of recrystallization, and even higher temperatures (600-700 ${ }^{\circ} \mathrm{C}$ ) can cause thermal fusion of clay minerals (Certini, 2005; Ulery and Graham, 1993).

In addition, findings of the previous laboratory tests support the increase in aggregate stability reported in the present study. An increase in aggregate stability was observed when the temperature increased from high $\left(550^{\circ} \mathrm{C}\right)$ to very high $\left(650{ }^{\circ} \mathrm{C}\right)$, in spite of soil carbon reduction (Thomaz and Fachin, 2014). Overall, the slash-and-burn system displayed immediate effects on some soil physical properties (Are et al., 2009; Thomaz et al., 2014).

Stable aggregates are desirable in order to reduce sealing, crusting, and erodibility (Le Bissonnais, 1996). However, little is known about the potential effects of increased stability on the functionality of aggregates in soil systems over medium to long-term periods (MataixSolera et al., 2011). In addition, it is necessary to know in agriculture fields if the aggregates affected by fire are less rich in nutrients, because the temperature may damage the chemistry, biology and fertility of the soil.

\section{Conclusions}

Fire temperature at soil surface in slash-and-burn agricultural systems is moderate to very high; however, the residence time of such temperatures is short. The temperature decreases abruptly at soil depth. Despite moderate-to-high temperatures, no carbon content depletion occurs at topsoil. However, significant changes in aggregate stability occur in this agricultural system.

Aggregate stability is naturally high in slash-andburn agricultural systems (> $80 \%$ ). However, aggregate stability increases even more (by $10 \%$ ) at the highest temperature, $660{ }^{\circ} \mathrm{C}$, an enhancement attributed to fire effects on topsoil. Conversely, the geometric mean diameter, that is, the most frequent aggregate class increases by $20 \%$ at moderate to high temperatures. Moreover, a temperature of $354^{\circ} \mathrm{C}$ does not affect the geometric mean diameter.

\section{Acknowledgments}

I thank Paulo Fachin, Claudio Antonio Kozechen and Tatiane Wouk for their support with the time-con- 
suming fieldwork and laboratory tests. I also thank the farmers from Tijuco Preto-Terra Cortada community for their collaboration in this research.

The research was supported by the Brazilian National Council for Scientific and Technological Development (CNPq - grant number 470587/2012-1), Araucaria Foundation (grant number 22537-11) and Supporter of Studies and Projects (FINEP) (grant PROINFRA - Project of Infrastructure 01/2009 - 0739/10 - AMBIOTEC - Advanced Center for Research in Environment and Biotechnology).

\section{References}

Amézketa, E. 1999. Soil aggregate stability: a review. Journal of Sustainable Agriculture 14: 83-151.

Are, K.S.; Oluwatosin, G.A.; Adeyolanu, O.D.; Oke, A.O. 2009. Slash and burn effect on soil quality of an Alfisol: soil physical properties. Soil and Tillage Research 103: 4-10.

Bento-Gonçalves, A.; Vieira, A.; Úbeda, X.; Martin, D. 2012. Fire and soils: key concepts and recent advances. Geoderma 191: 3-13.

Bodí, M.B.; Martin, D.A.; Balfour, V.N.; Santín, C.; Doerr, S.H.; Pereira, P.; Cerdà, A.; Mataix-Solera, J. 2014. Wildland fire ash: production, composition and eco-hydro-geomorphic effects. Earth-Science Reviews 130: 103-127.

Brevik, E.; Cerdà, A.; Mataix-Solera, J.; Pereg, L.; Quinton, J.; Six, J.; Van Oost, K. 2015. The interdisciplinary nature of SOIL. Soil 1: 117-129.

Bruun, T.B.; Neergaard, A.; Lawrence, D.; Ziegler, A.D. 2009. Environmental Consequences of the demise in swidden cultivation in southeast Asia: carbon storage and soil quality. Human Ecology 37: 375-388.

Castro Filho, C.; Lourenço, A.; Guimarães, M.F.; Fonseca, I.C.B. 2002. Aggregate stability under different soil management systems in a red latosol in the state of Paraná, Brazil. Soil and Tillage Research 65: 45-51.

Caviglione, J.H.; Kiihl, L.R.B.; Caramori, P.H.; Oliveira, D. 2000. Paraná climate charts $=$ Cartas climáticas do Paraná. Iapar, Londrina, PR, Brazil. (CD-ROM) (in Portuguese).

Cerdà, A.; Doerr, S.H. 2008. The effect of ash and needle cover on surface runoff and erosion in the immediate post-fire period. Catena 74: 256-263.

Cerri, C.E.P.; Sparovek, G.; Bernoux, M.; Easterling, W.E.; Melillo, J.M.; Cerri, C.C. 2007. Tropical agriculture and global warming: impacts and mitigation options. Scientia Agricola 64: 83-99.

Certini, G. 2005. Effects of fire on properties of forest soils: a review. Oecologia 143: 1-10.

DeBano, L.F. 2000. The role of fire and soil heating on water repellency in wildland environments: a review. Journal of Hydrology 231-232: 195-206.

DeBano, L.F.; Neary, D.G.; Ffolliott, P.F. 1998. Fire's Effects on Ecosystems. Wiley, New York, NY, USA.

Doerr, S.H.; Cerdà, A. 2005. Fire effects on soil system functioning: new insights and future challenges. International Journal of Wildland Fire 14: 339-342.

Grau, A.; Brown, A.D. 2000. Development threats to biodiversity and opportunities for conservation in the mountain ranges of the upper Bermejo river basin, NW Argentina and SW Bolivia. AMBIO: A Journal of the Human Environment 29: 445-450.
Hedo, J.; Lucas-Borja, M.; Wic, C.; Andrés-Abellán, M.; Las Heras, J. 2015. Soil microbiological properties and enzymatic activities of long-term post-fire recovery in dry and semiarid Aleppo pine (Pinus halepensis M.) forest stands. Solid Earth 6: 243.

Hillel, D. 1998. Environmental Soil Physics: Fundamentals, Applications, and Environmental Considerations. Elsevier Science, Amsterdam, The Netherlands.

IUSS Working Group WRB. 2006. World Reference Base for Soil Resources: A Framework for International Classification, Correlation and Communication. FAO, Rome, Italy. (World Soil Resources Reports, 103).

Keeley, J.E. 2009. Fire intensity, fire severity and burn severity: a brief review and suggested usage. International Journal of Wildland Fire 18: 116-126.

Keesstra, S.; Geissen, V.; Mosse, K.; Piiranen, S.; Scudiero, E.; Leistra, M.; van Schaik, L. 2012. Soil as a filter for groundwater quality. Current Opinion in Environmental Sustainability 4: 507-516.

Keesstra, S.; Maroulis, J.; Argaman, E.; Voogt, A.; Wittenberg, L. 2014. Effects of controlled fire on hydrology and erosion under simulated rainfall. Cuadernos de Investigación Geográfica 40: 269-293.

Lasanta, T.; Cerdà, A. 2005. Long-term erosional responses after fire in the central Spanish Pyrenees. 2. Solute release. Catena 60: 81-100.

Le Bissonnais, Y. 1996. Aggregate stability and assessment of soil crustability and erodibility. I. Theory and methodology. European Journal of Soil Science 47: 425-437.

Liao, C.; Feng, Z.; Li, P.; Zhang, J. 2015. Monitoring the spatiotemporal dynamics of swidden agriculture and fallow vegetation recovery using Landsat imagery in northern Laos. Journal of Geographical Sciences 25: 1218-1234.

Mataix-Solera, J.; Cerdà, A.; Arcenegui, V.; Jordán, A.; Zavala, L.M. 2011. Fire effects on soil aggregation: a review. EarthScience Reviews 109: 44-60.

Mukul, S.A.; Herbohn, J. 2016. The impacts of shifting cultivation on secondary forests dynamics in tropics: a synthesis of the key findings and spatio temporal distribution of research. Environmental Science \& Policy 55: 167-177.

Ngo-Mbogba, M.; Yemefack, M.; Nyeck, B. 2015. Assessing soil quality under different land cover types within shifting agriculture in south Cameroon. Soil and Tillage Research 150: 124-131.

Obale-Ebanga, F.; Sevink, J.; Groot, W.; Nolte, C. 2003. Myths of slash and burn on physical degradation of savannah soils: impacts on Vertisols in north Cameroon. Soil Use and Management 19: 83-86.

Pereira, P.; Cerdà, A.; Úbeda, X.; Mataix-Solera, J.; Arcenegui, V.; Zavala, L. 2015. Modelling the impacts of wildfire on ash thickness in a short-term period. Land Degradation \& Development 26: 180-192.

Shakesby, R.; Doerr, S. 2006. Wildfire as a hydrological and geomorphological agent. Earth-Science Reviews 74: 269307.

Silva-Forsberg, M.C.; Fearnside, P.M. 1997. Brazilian Amazonian caboclo agriculture: effect of fallow period on maize yield. Forest Ecology and Management 97: 283-291. 
Smith, P.; Cotrufo, M.; Rumpel, C.; Paustian, K.; Kuikman, P.; Elliott, J.; McDowell, R.; Griffiths, R.; Asakawa, S.; Bustamante, M. 2015. Biogeochemical cycles and biodiversity as key drivers of ecosystem services provided by soils. Soil 1: 665-685.

Tanaka, S.; Kendawang, J.J.; Yoshida, N.; Shibata, K.; Jee, A.; Tanaka, K.; Ninomiya, I.; Sakurai, K. 2005. Effects of shifting cultivation on soil ecosystems in Sarawak, Malaysia. IV. Chemical properties of the soils and runoff water at Niah and Bakam experimental sites. Soil Science and Plant Nutrition 51: 525-533.

Thomaz, E.L. 2013. Slash-and-burn agriculture: establishing scenarios of runoff and soil loss for a five-year cycle. Agriculture, Ecosystems \& Environment 168: 1-6.

Thomaz, E.L.; Antoneli, V.; Doerr, S.H. 2014. Effects of fire on the physicochemical properties of soil in a slash-and-burn agriculture. Catena 122: 209-215.

Thomaz, E.L.; Fachin, P.A. 2014. Effects of heating on soil physical properties by using realistic peak temperature gradients. Geoderma 230-231: 243-249.

Tisdall, J.; Oades, J.M. 1982. Organic matter and water-stable aggregates in soils. Journal of Soil Science 33: 141-163.

Úbeda, X.; Outeiro, L. 2009. Physical and chemical effects of fire on soil. p. 105-132. In: Cerda, A.; Robichaud, P.R., eds. Fire effects on soils and restoration strategies. CRC Press, Boca Raton, FL, USA.
Ulery, A.L.; Graham, R. 1993. Forest fire effects on soil color and texture. Soil Science Society of America Journal 57: 135-140.

van Vliet, N.; Mertz, O.; Heinimann, A.; Langanke, T.; Pascual, U.; Schmook, B.; Adams, C.; Schmidt-Vogt, D.; Messerli, P.; Leisz, S.; Castellaj, J.C.; Jørgensena, L.; Birch-Thomsena, T.; Hettb, C.; Bech-Bruunk, T.; Ickowitzl, A.; Vum, K.C.; Yasuyukin, K.; Foxo, J.; Padochp, C.; Dresslerq, W.; Zieglerr, A.D. 2012. Trends, drivers and impacts of changes in swidden cultivation in tropical forest-agriculture frontiers: a global assessment. Global Environmental Change 22: 418-429.

Walkley, A.; Black, I.A. 1934. An examination of the Degtjareff method for determining soil organic matter, and a proposed modification of the chromic acid titration method. Soil Science 37: 29-38.

Wang, C.; Wang, G.; Wang, Y.; Rafique, R.; Ma, L.; Hu, L.; Luo, Y. 2015. Fire alters vegetation and soil microbial community in alpine meadow. Land Degradation \& Development. DOI: 10.1002/ldr.2367. 